\title{
Employment Policy and International Labour Standards
}

\section{Kesiana Çoçka}

Phd, candidates, Faculty of Law, UT

Email:kesiana_cocka@yahoo.com

\section{Armela Maxhelaku}

External pedagogue, Faculty of Law, UT

Email: amaxhelaku@hotmail.com

\section{Prof.Asoc.Dr. Ilir Rusi}

Effective pedagogue, Faculty of Law, UT Email: ilirusi@yahoo.com

\section{Doi:10.5901/mjss.2017.v8n1p366}

\begin{abstract}
The purpose of this paper is to give some general considerations on employment policy and international labour standards. This paper examines the context and the obligations under Convention no. 122, specifically: to declare an employment policy and to identify objectives of policies that can be implemented. It is important to mention that, this Convention, is one of the most important conventions that has defined the detail procedures regarding drafting and implementation of employment policies. According to this Convention, it is mandatory the involvement of representatives persons involved, in drafting and operation processes of employment policies. In this regard, authorities should take appropriate measures to secure that employers rights are respected and take into account their experience, views and opinions concerning employment policies. In order to stimulate economic growth, each member state should implement an active policy, in order to provide work for any person who was willing and able to work and an economic situation in which all available labor resources are being used. Furthermore in this paper will be identified general and selective measures, which are defined in Employment Policy Recommendation, 1964 (No. 122). The paper is focused especially on analyzing different issues regarding active labour market policies and employment policies. An important part of this paper, is the analysis of the flexibility in the labour market background, definitions of flexicurity, also security and flexibility in labour markets.
\end{abstract}

Keywords: Employment policy, international labour standards, labour market policies, flexibility and security.

\section{Introduction}

International labour standards play a key role in guaranteeing and respecting rights of all subjects involved in employment system. Since 1919, the International Labour Organization has developed a system of international labour standards aimed at promoting opportunities for women and men to obtain decent and productive work in conditions of freedom, equity, security and dignity. In today's globalized economy, international labour standards are an essential component in the international framework for ensuring that the growth of the global economy provides benefits to all.(Rules of the Game: A brief introduction to International Labour Standards, 2014)

International labour standards are the fundamental part of the International Labour Organization`s strategy, which aims to promote globalization, development, reducing poverty and guarantee dignity and safety for workers and employers. One of the most important documents, is The Declaration on Social Justice for a Fair Globalization. This Declaration affirmed that International Labour Organization must apply and develop that policies which set standards, in accordance with the world of work and also that policies which can help in promoting and achieving the mission of the Organization.

\section{International Labour Standards and Employment Policy}

We can refer to international labour standards, as some legal instruments developed by the ILO's integral parts, such as 
workers, employers and governments, which promote fundamental principles and rights at work. They can be either legally binding Conventions, specifically international treaties that member States should ratify, or recommendations, that are non-binding legal acts. Mostly, a Convention sets out the fundamental principles that should be adopted by countries that have ratified this Convention, while a Recommendation is a legal act which complements the Convention by setting out more detailed rules and instructions on how it could be implemented. Despite this, a recommendation can also be independent, so it can not be related to any Convention. It is important to mention that Recommendations and Conventions are developed by representatives of workers, employers and governments, and then they are adopted at the ILO's annual International Labour Conference. Referring to ILO's Constitution, all member States are obliged to send the adopted standard to the respective competent authority, which ordinarily can be the parliament, in order to take the approval document, which is called "consideration". This process, in the case of Conventions, is called "consideration for ratification". In case that a Convention is ratified, as a binding legal act, a Convention usually comes into force one year after the date of ratification from a specific country. After ratifying the Convention, ratifying countries are required to adopt the Convention in national law, to apply it and then to give a report or feedback, in regular periods of time, on issues related to the application of the Convention. If it is required by countries, International Labour Organization can offer technical assistance for different cases. According to cases, in which a country breaches the ratified Convention, the competent authorities can commence complaint procedures or representation procedures.

International labour standards elaborate the concept that several action needs to be taken on a specific issue, for example providing work for women with maternity protection, or providing safe and secure working conditions for horticultural workers. Evolving international labour standards, at the International Labour Organization, is a particular legislative process, that involves representatives of three actors, employers, workers and governments from all around the world. This legislative process is initiated from the Governing Body, which has the competence that, after agreeing on the issue, to put this issue on the agenda of a future International Labour Organization Conference. Then, the second step is the preparation of the report from the International Labour Office. This report offers an analyses of the laws, regulations, rules and practices of member States, related to the issue that is going to be discussed. It is mandatory, to represent and to submit this report to all the member States and also to different employers and workers organizations, in order to give them the opportunity to make comments and then to argue and review it at the International Labour Conference. There is also a second report that is prepared by the International Labour Office, together with a draft document for comments and is presented for discussion at the following International Labour Conference, where this document is proposed for adoption. There is also a specific procedure called "double discussion", which is applied and gives to the participants of the Conference enough time to analyze the draft instrument and discuss on it. It is required a two-thirds majority of votes, in order to adopt a standard. In this regard, in order to adopt international labour standards, it is required to bring together delegations from all International Labour Office member States and each of them consist of government delegates, specifically one worker delegate and one employer delegate, which has one vote in plenary.

\section{The Context and the Obligations under Convention no. 122}

\subsection{The context of Convention No. 122}

Convention No. 122 illustrates the symbiosis between policy and rights. As a policy Convention, it articulates specific goals and the policies and programmes required for their achievement. But it is also a normative instrument: The states which ratify the Convention commit themselves and obtain different obligations, for instance the ratifying countries are required to take into consideration tripartite consultations, in formulating the policies. The employment policy goals are represented as a very important goal of the macroeconomic policy and for this reason the scope of the Convention consists of a very broad range of issues, such as social and financial matters, referring to ILO employment policy documents and discussions. The obligations related to the Convention include those deriving from membership of the ILO and particularly engagement with the supervisory processes. Convention No. 122 has proved an authoritative and popular statement of the role and goals of employment policy.

Convention No. 122 sets out the basic principles regarding the employment policies, which were first adopted by the ILO's World Employment Conference in 1976 and other ILO instruments, which were ratified in the following decades and developed different elements of employment policy. Over the past few decades, many other member States have also articulated or adopted policies and programmes, which were focused on promoting full and productive employment. Convention No. 122 has been ratified by many OECD countries, including Canada, the Member States of the European Union and Japan, as well as by Brazil, China, India and the Russian Federation. This Convention is also ratified from a great number of developing countries, which are taking steps towards its implementation through developing and 
implementing employment promotion policies and measures. Despite this, the real challenge remains the formulation and implementation of a national employment policy in accordance with the provisions of Convention.

The basic objective of Convention No. 122 is to see as a major goal, the implementation of that national policy, which promotes full and productive employment. In basic objectives is also involved the "freely chosen" element, with the purpose of ensuring the elimination of discrimination and creating opportunities to assure skills. There is a connection between the goal of full and productive employment and other economic and social objectives. In this context the most important element is first of all national level of development and other social and economic objectives. It is important to mention that representatives of employers and workers, as well as representatives of employers and workers involved in the rural economies, should be consulted on the formulation of employment policies and particularly on their application.

\subsection{The obligations under Convention No. 122}

First of all the Convention requires ratifying states to see as a major goal, the implementation of that national policy, which promotes full and productive employment. Regarding Article 1 of the Convention, employment policies shall ensure that people who are available and are looking for a work, to find and offer a productive work. In addition ratifying states are obliged to formulate and implement such policies, which shall aim at ensuring that people are free to choose their work, to find the appropriate work for which they are qualified for, to use their skills and to avoid all types of discrimination, such as on basis of color, religion, sex, race, national extraction, social origin or political opinion.

The Convention recommends that, employment policy shall take into consideration some essential elements, such as the level of economic development and the connection between the level of economic development, employment, social and economic objectives. The employment policies shall take due account to methods that are suitable to adopt in specific conditions of each ratifying state. Regarding Article 2 of the Convention, each member shall aim at ensuring, by applying the right methods and tools that are suitable for several conditions of a ratifying state and decide, after taking into consideration the economic and social factors, the measures and steps that is needed to be adopted for achieving the objectives stated in Article 1 of the Convention and also the programmes that needs to be developed, in order to fulfill the objectives and to apply this measures.

Full employment is not inconsistent with a degree of frictional (short-term) unemployment. ILO standard definitions and workforce surveys analyzing the different aspects of this phenomenon are widely used. First of all, productive employment. High value is clearly given to productivity among national economic objectives. Evidently, the greatest challenges that arise in this respect are at the informal end of the employment spectrum. Low productivity is a common feature of both rural and urban poverty. Referring to the application of Convention No. 122, the Committee of Experts states that the reduction of informal work is normally followed by an increase in productivity. Measures taken in relation to the informal economy should aim to provide enterprises in the informal economy with greater access to such elements, which facilitate this process. Member States provide information in their reports on the steps that ratifying states take in order to achieve the objectives of the Convention No. 122, in the framework of the informal economy, with the aim of transformation to the formal economy.

Second, freely chosen employment. The "Employment and Occupation" Convention No. 111, which entered into force in 1958, also prevents all types of discrimination in employment, such as discrimination on the basis of color, political opinion, race, national extraction, social origin and religion. This prohibition encompasses discrimination in relation to engagement, promotion, termination or any other conditions of employment. But it also calls for equal opportunities to be asserted and for active methods to be applied, in order to ensure equal opportunities, paying attention to vulnerable categories, including youth, migrants, older workers, indigenous peoples and workers with disabilities, not only with aim to prevent all the types of discrimination against them, but also to enhance their skills and employability.

Women make up around half of the population (or, in other words, half of human resources and human capital). This means that the situation of girls and women workers needs to be addressed in all countries, particularly by examining the gender relations at play in education and training, the gender division of labour and of property distribution. The employment policies can be successful, only if they are connected to households and social protection systems, which makes it impossible to ignore the need to strengthen the position of women in the employment issues. Employment policies are accordingly crucial in giving practical effect to the right related to free choices for both women and men workers. This complements the rights-based approach to equality advocated by the ILO, in which the right of equal compensation or remuneration for the same work for women and men workers, has a specific importance, in addition to maternity protection and policies and measures for that category of workers, engaged with family obligations. Regarding to young people, in 2012 the Resolution was adopted by ILC following the discussion on the youth employment crisis emphasizes that employment policies can facilitate the access of young people in the labour market. It is required that 
employment policies needs to be comprehensive and to specify the rights for most disadvantaged youth, as well as broad social and economic benefits through increased equality and social inclusion. The 2012 Resolution requires for employment policies aim at ensuring that there is an effectively contribution in creating jobs for young people. (Guide on employment policy and international labour standards, 2013).

It is also important to mention Employment Policy Recommendation, 1964 (No. 122), which requires that Employment policy should be establish from a broad analysis of the essential elements such as employment, labour force, underemployment and unemployment. Also it is required to obtain the data from the appropriate resources, which will help in arranging information and should be devoted to the preparation of detailed studies and then in circulating this documents to involved persons. Regarding article 5 of this recommendation, each member state should make efforts to fully develop human capacities, through different mechanisms, for example through vocational guidance, education, health services and training, and should keep a suitable balance regarding these different purposes, should take the appropriate initiatives to help workers and young people, in finding productive and relevant employment and to assist them to be prepared for the changing needs of the economy.

There are also other Relevant ILO instruments, such as Vocational Rehabilitation and Employment (Disabled Persons) Convention, 1983 (No. 159), Employment Service Convention, 1948 (No. 88), Private Employment Agencies Convention, 1997 (No. 181), Older Workers Recommendation, 1980 (No. 162), Promotion of Cooperatives Recommendation, 2002 (No. 193) and Job Creation in Small and Medium-Sized Enterprises Recommendation, 1998 (No. 189).

\section{Active Labour Market Policies and Flexibility and Security}

\subsection{Active labour market policies}

Since the 1990s there has been an increased request of the need to strengthen the relationship between employment, labour market policies and social protection. These types of policies are widely considered as an important and necessary mechanism in reducing unemployment. As a result, most economically developed countries have increased expenses for implementation of ALMPs (Active labour market policies). But it is important to mention that this process has not always been positive. A well-established microeconomic literature exists today on the effects of these policies and their design and delivery systems at the individual level.

The overall effects of ALMPs, however, have been less documented. Macroeconomic evaluations of ALMPs have not been carried out systematically yet, at least not taking into account implementation characteristics. In fact, few comprehensive studies centered specifically on the effects of ALMPs have been carried out since the beginning of the 90 s and they reflect different approaches with regards to the effect of Active labour market policies on unemployment and employment level. While Layard et al. (1991) find that ALMPs have a negative effect on long-term unemployment, the OECD (1993) argues that results are not robust enough to be conclusive. More recently, Estevão (2003) found positive effects of ALMPs on the employment rate of the business sector in the 1990s but not in the late 1980s. Importantly, studies in which the effectiveness of ALMPs is linked to implementation aspects are even scarcer. As such, existing knowledge on the aggregate effects of activation measures and their design remains inconclusive. (Verónica, 2015)

Active labour market policies aim to create employment in two ways: first of all by implementing the appropriate measures, which support creating and generating, for example promoting public works, stimulating undertakings and enterprises and also by giving subsidies. The second way which is used to create employment is related with trainings, offering and providing full information and also by ensuring efficient labour exchanges. It can also be used indirect measures in macroeconomic level, promoting public works policies and programmes. One important aspect is also Collective bargaining. Collective bargaining consist of a process of negotiation between employees and employers aimed at arraigning and regulating works conditions, benefits, working salaries and other aspects. This process can facilitate the implementation of those policies, which aims to create and ensure equality in employment.

With today's openness to trade and investment, continuous technological progress and privatization of state-owned enterprises, labour market change is inevitable. In many cases, these changes result not only in internal reallocation of labour but also lay-offs. As a consequence, governments and the social partners must find ways to cope with such changes. ALMPs are an important policy tool for addressing the adverse effects of structural change and insufficient labour demand, thereby creating security in change, although they are not a substitute for macroeconomic policies of economic growth and employment creation. In the absence of a favourable macro environment for increased investment, growth and employment, ALMPs can only provide temporary support to those displaced by structural and business cycle change. 
Active policies must contribute to the reallocation of workers made redundant, while offering them replacement incomes during transition. In such a way, ALMPs not only contribute to security in change but also to employment, productivity and economic growth, at least in the longer term. Several units of the Office have already conceptualized and advised constituents on such active ways of coping with redundancies (e.g. socially responsible restructuring, communitybased restructuring, etc. (Active labour market policies, 2003). Regarding recent developments in ALMPs, it is important to mention activation of labour market policies, activation of in-work benefits, transitional labour markets, employment and competitiveness pacts, territorial employment pacts, Local development boards and community-based restructuring.

\subsection{Flexibility and security}

Since both flexibility and security are in fact multidimensional concepts, it is not surprising that a broader view has emerged in the European context. In this respect, labour market flexibility can be seen as the degree to which employment and/or working time (labour input adjustment) or wages (labour cost adjustment) can vary with the business cycle and structural changes to the economy. Moreover, flexibility can be seen in terms of external versus internal adjustment; the former referring to job changes involving a different employer and to labour turnover and geographic mobility, while the latter refers to job changes within the same enterprise. Flexibility can also be viewed as consisting of either numerical or functional adjustment; the former relating to changes in the number of workers, while the second element means occupational changes and mobility within the enterprise. The adjustment process may thus take place through external (or internal) numerical flexibility, functional flexibility or wage flexibility. This process will in turn depend on the hiring and firing rules (due to employment protection legislation), the ability to use temporary workers (also determined by legislation), the possibility for employers to change working time, and the ability to outsource or to change the organization of work. The important point here is that flexibility is not just about being able to easily hire and fire workers but more generally about the ability for employers to adjust in response to changes in economic conditions or structural trends.

Security can also be described along different dimensions: job security, labour market security, employment protection and income security. Job security entails the protection of a particular job, i.e. traditional employment protection legislation, while employment security refers to the protection of employment but not necessarily in the same job or for the same employer, which is supported by labour market policies. Income security consists of protection to earnings provided by social security. A comprehensive approach to security (though employment security, labour market policies and social rights) can also be defined as labour market security. These multiple dimensions of both flexibility and security and their potential combinations clearly show that there isn't a one-size-fits-all model. Although there has been considerable discussion on the Danish flexicurity model as a 'golden triangle' of flexible hiring and firing rules, generous income security and active labour market programmes, it is just one illustration of those possible combinations. (Cazes \& Verick, 10)

Flexicurity represents a policy strategy that can be defined as follows: a policy strategy that attempts, synchronically and in a deliberate way, to enhance the flexibility of labour markets, the work organization and labour relations on the one hand, and to enhance security - employment security and social security - notably for weaker groups in and outside the labour market on the other hand. Clearly the definition presented above is rather strict due to the elements of 'synchronization', 'coordination' and 'weaker groups'. Indeed, in order to render it possible to empirically research flexicurity a strict definition of the concept is required. (The Concept of "Flexicurity": A new approach to regulating employment and labour markets , 2003). Flexicurity refers to the combination of flexible labour markets and a high level of employment and income security and is seen with the EU as the answer to the dilemma of how to maintain and improve competitiveness whilst preserving the European social model. One aspect to flexicurity is the promotion of flexible forms of working that will let more people participate in the labour market by giving them the possibility to balance work with other commitments. However, most social security systems were established to support the majority of workers in full-time regular employment and unless these are adapted to cater for atypical situations there is a clear risk of promoting flexibility without security. Given the current political emphasis on promoting flexicurity and monitoring of progress towards common goals, indicators to measure the extent to which people in flexible forms of employment are covered by social protection are of great interest.(Flexicurity: indicators on the coverage of certain social protection benefits for persons in flexible employment in the european union, 2009).

\section{Conclusions}

- International labour standards provide the basic essential social standards. 
- International labour standards cover this issues: wages, forced labour, social inclusion, basic rights for workers and employers, employment and unemployment policies, child and youth labour, equal opportunities and chances, equal compensation for the work with the same value etc.

- International Labour Organization aims to elaborate international labour standards and also in ensuring that these standards are implemented by governments.

- International labour standards are materialized in ILO's legal tools, such as Conventions and Recommendations, respectively binding or non-binding guidelines.

- "Employment Policy" Convention No.122, entered into force in 1964, promotes productive and full employment, which are considered as a major goal.

- It is important for the representatives of workers and employers, to be involved in drafting, formulation and application processes of employment policies.

- The application of policies, regarding security and flexibility, can be effective and helpful for representatives of employers and employees.

- Employment policies require close cooperation between ministries and key institutions that implement them.

- There are 8 ILO's fundamental Conventions, developing and elaborating fundamental rights, which are legally binding guidelines.

- "Employment Policy" Convention No. 122, entered into force in 1964 is an important legal instruments, which plays a vital role in ensuring that national policy efforts give sufficient importance to the issue of employment.

- The better combination of flexibility and security, can effect employment, income and social protection.

- There is a discussion regarding flexicurity, what it is and can it work only on specific conditions.

\section{References}

Active labour market policies. (2003). International Labour Office , 6-7.

Cazes, S., \& Verick, S. (10). What role for labour market policies and institutions in development? International Labour Office , 5-6.

Flexicurity: indicators on the coverage of certain social protection benefits for persons in flexible employment in the european union. (2009).

Guide on employment policy and international labour standards. (2013). International Labour Office , 21, 24-25.

Rules of the Game: A brief introduction to International Labour Standards. (2014). International Labour Organization , 7,10,14,15

The Concept of "Flexicurity": A new approach to regulating employment and labour markets . (2003). Wilthagen, Ton; Tros, Frank , 3-4.

Verónica, E. (2015). Are active labour market policies effective in activating and integrating low-skilled individuals? An international comparison. International Labour Office, 1. 